\title{
Cutaneous myiasis due to Dermatobium hominis in Winnipeg
}

\author{
David J Musto BA MD, Kenneth A Murray MD FRCSC, FACS
}

\begin{abstract}
DJ Musto, KA Murray. Cutaneous myiasis due to Dermatobium hominis in Winnipeg. Can J Plastic Surg 2003;11(1):41-42.
\end{abstract}

Cutaneous myiasis is an uncommon infestation in $\mathrm{N}$ orth A merica, with most cases arising in travelers who have recently returned from Central and South A merica. The majority of cases are due to Dermatobium hominis and present with a furunculoid nodule with local inflammation. The case reported is of a 57-year-old woman with cutaneous myiasis contracted in W innipeg, $\mathrm{M}$ anitoba.

Key Words: Dermatobium hominis; Larvae; M yiasis

\section{C as de myiase cutanée due à $D$ ermatobium hominis à Winnipeg}

RÉSU MÉ : La myiase cutanée est une affection rare en A mérique du $N$ ord et elle se rencontre surtout chez les voyageurs revenus depuis peu de I'A mérique centrale et de I'A mérique du Sud. La plupart des cas sont dus à $D$ ermatobium hominis et ils se manifestent par un nodule furonculoïde et de l'inflammation locale. Voici le cas d'une femme de 57 ans, atteinte de myiase cutanée contractée à W innipeg.
$M$ yiasis is an infection of living vertebrate tissue by the larvae of dipterous (two-winged) flies. There are several manifestations of these infections, including cutaneous, gastrointestinal, urogenital, nasopharyngeal and ophthalmomyiasis. The most common form is the cutaneous infection, which can present as furunculoid, subcutaneous infestation with tunnel formation, wound infestation and subcutaneous infestation with migratory swelling. Although it is endemic to tropical regions, there have been reports of infections in $\mathrm{N}$ orth $\mathrm{A}$ merica $(1,2)$. T he present report describes a rare case of cutaneous myiasis acquired in $\mathrm{M}$ anitoba, followed by a discussion of myiasis and the particular subspecies involved in this case.

\section{A SE PRESEN TAT ION}

A 57-year-old woman presented to the emergency department on A ugust 28, 2001 complaining of an insect bite to her left cheek. This bite had occurred two weeks earlier while the patient was in her backyard in Winnipeg, Manitoba. The patient recalled being bitten by a mosquito, wasp or bee. For the following four days, the patient sought no treatment. A gradual swelling and redness devel oped over this time period. On the fifth day, the patient went to her general practitioner, who prescribed erythromycin.

Despite taking antibiotics, the redness and swelling continued to worsen and approximately five days after her first visit, she reattended her physician. On this visit, the physician stopped the treatment with erythromycin and prescribed penicillin by mouth.

During the five days after her visit, the patient reported a serosanguinous discharge coming from a small punctum at the site of the original sting.
Following the change in antibiotics, the erythema continued to progress, as did the discharge. Two days before her presentation to the emergency department she complained of a soreness developing on the globe on the left side.

A the time of assessment in the emergency department, the patient had a left periorbital cellulitis extending to the left cheek. The skin of the upper cheek was excoriated, erythematous and edematous. A white blood cell count was $11.3 \times 10^{9} \mathrm{~L}$. Of note, there was a corneal abrasion to the left eye, which responded to appropriate treatment. There was a definable punctum over the point of maximal swelling. A small insect larva appeared to be protruding intermittently from the punctum on her cheek. On squeezing her cheek on both sides of the punctum, a white insect larva approximately $10 \mathrm{~mm}$ in length was expressed through the punctum onto the cheek skin, as was some whitish purulent material. The larva was then sent to the microbiology laboratory, where it was identified as being of the D ermatobium species. Infectious diseases specialists were consulted for advice on antimicrobial therapy.

U pon removal of the larva, the patient's cellulitis completely resolved.

\section{DISC USSION}

Dermatobium hominis, an obligate parasite, is a member of the oestrodiae superfamily, the oestridae family and the cuterebrinae subfamily (3). It is also known as the human botfly and is endemic to tropical M exico, South A merica, C entral A merica and Trinidad. The lifecycle of the fly is quite interesting in that the female of the species will seize a blood-sucking insect, such as a mosquito, and place eggs on the abdomen of the carrier.

St Boniface G eneral H ospital, W innipeg, M anitoba

C orrespondence: Dr DJ M usto, The U niversity of M anitoba Section of Plastic Surgery, G C 413 H ealth Sciences C entre,

820 Sherbrook Street, W innipeg, M anitoba R3A 1R9. Telephone 204-787-1485, fax 204-787-4837, e-mail busydoc@shaw.ca 
W hen the mosquito bites a warm-blooded animal, the local heat induces the larva to hatch and drop to the skin as a stage I larva, or first instar. The larva penetrates the skin of the animal directly, or through a defect produced by the insect bite, and develops in the subcutaneous tissue. The larva proceeds through a second and third stage, or instar, in the subcutaneous tissue and then, after five to 10 weeks, the third instar emerges and drops to the ground where it forms flies over the span of two to three weeks.

Cutaneous myiasis is most often seen on areas of the body that are exposed, with Dermatobium hominis showing preference for the head, arms and legs (4-6). The principle manifestations of infestation are erythema, pruritis, edema and a furuncular nodule with a punctum in the area of the developing larvae. A local inflammatory reaction is almost always seen. Pain can be an associated finding. A discharge is commonly seen, which may be serous, serosanguinous or seropurulent. Secondary bacterial infection may also occur with systemic signs of infection, such as fever, malaise and lymphadenopathy.

Treatment of an infestation of $D$ ermatobium hominis is complete removal of the larvae. M anual expression, as in the present case, may be adequate, but surgical excision is preferred to ensure the removal of the larvae in its entirety (7). A ny leftover portion of the larvae will incite further inflammation. The surgical excision may be performed under local analgesia with relative ease. Some authors have suggested that the infiltration of lidocaine is enough to express the larvae $(8,9)$. A nother option for removal of the larvae is the occlusion of the punctum. This procedure forces the larvae to surface in order to avoid asphyxiation. Various substances, such as petroleum jelly, raw meat or fat (9-11), and gum have been tried. The main problems with this technique are that the larvae may asphyxiate without sur- facing or the larvae may take up to $24 \mathrm{~h}$ to surface. If a secondary bacterial infection occurs, antibiotics will be needed.

\section{CONCLUSION}

Although uncommon in North A merica, the frequency of travel to tropical and exotic climates may make cutaneous myiasis a condition that could be seen from time to time. Furthermore, the above case report demonstrates that this uncommon and unusual infestation is a possibility in $\mathrm{C}$ anada.

\section{REFEREN CES}

1. Rao R, N osanchuk JS, M ackenzie R. C utaneous myiasis acquired in N ew York State. Pediatrics 1997;99:601-2

2. Baird JK, Baird CR, Sabrosky CW. N orth A mercan cuterebrid myiasis. Report of seventeen new infections in human beings and review of the disease. J A m A cad Dermatol 1989;21:763-72.

3. Mathieu EM, W ilson BB. M yiasis. In: M andell GL, Bennett JE, Dolin R, eds. Principles and Practice of Infectious Diseases, 5th edn. N ew York: Churchill Livingstone 2000:2976-9.

4. Tsuda S, N agaji J, Kurose K, M iyasato M, Sasai Y, Yoneda $Y$. Furuncular cutaneous myiasis caused by dermatobium hominis larvae following travel to Brazil. Int I Dermatol 1996;35:121-3.

5. Jelinek T, N othdurft HD, Rieder N, Löscher T. C utaneous myiasis: review of 13 cases in travellers returning from tropical countries. Int J Dermatol 1995;34:624-6.

6. G ordon PM, H epburn N C, W illiams A E, Bunney M H. Cutaneous myiasis due to Dermatobia hominis: a report of six cases. $\mathrm{Br}$ J Dermatol. 1995;132:811-4.

7. Rosen J, N euberger D. M yiasis Dermatobia hominis, linn. Report of a case and reiew of the literature. Cutis 1977;19:63-6.

8. Loong PT, Lui H, Buck HW. Cutaneous myiasis: a simple and effective technique for extraction of Dermatobium hominis larvae. Int J Dermatol 1992;31:657-9.

9. N unzi $E$, Rongioletti F, Rebora A. Removal of Dermatobia hominis larvae. A rch Dermatol 1986;122:140.

10. Brewer TF, W ilson M E, Gonzalez E, Felsenstein D. Bacon therapy and furuncular myiasis. JA M A 1993;270:2087-8.

11. Bernhard JD. Bringing on the bacon for myiasis. Lancet 1993;342:1377-8. 